\title{
Geografická reprezentativita poslanců zvolených do Poslanecké sněmovny českého parlamentu za první republiky (1918-1938) a po roce $1989^{1}$
}

\author{
The geographical representativeness of deputies elected to the Chamber of \\ Deputies of the Czech Parliament during the First Republic (1918-1938) \\ and after 1989
}

\section{RENÁTA MIKEŠOVÁ, TOMÁŠ KOSTELECKÝ}

\begin{abstract}
Election laws regulate the number of deputies who are elected in individual electoral districts, and set them in relation to the population, respectively to the number of voters participating in elections in individual regions. Elected deputies could thus be regarded as political representatives of citizens living in electoral districts. However, under systems of proportional representation, current deputies represent the ideology of the party to which they belong rather than the region. Nevertheless, it makes sense to study the spatial distribution of the places of origin and residence of members of parliament and their changes over time, because it suggests much about the political system and the system of representative democracy in the country. The spatial distribution of places of residence of candidates and elected members indicates not only the territorial proportionality and geographic representativeness, but also the shifting centers of political power. The analysis clearly confirms the gradual decentralization and regionalization of political power in the country, which stands in contrast to the centralization of power in the economy, this latter trend apparent from the concentration of economic management and decision-making in the largest cities, especially in Prague.
\end{abstract}

Keywords: Elections; Geographic Representativeness; Centralization and Decentralization

1 Článek byl vytvořen s podporou grantu GAČR, reg. č. P408/12/1442 „Stabilita a změny prostorových vzorců volebních preferencí na území České republiky od zavedení všeobecného hlasovacího práva - příciny a důsledky“.

2 Renáta Mikešová: Katedra sociální geografie a regionálního rozvoje, Přírodovědecká fakulta Univerzity Karlovy; Sociologický ústav Akademie věd ČR, v.v.i. / Department of Social Geography and Regional Development, Faculty of Science, Charles University, Prague, Czech Republic; Institute of Sociology of the Czech Academy of Sciences, Prague, Czech Republic. E-mail: renata.mikesova@soc.cas.cz.

Tomáš Kostelecký: Sociologický ústav Akademie věd ČR, v.v.i./ Institute of Sociology of the Czech Academy of Sciences, Prague, Czech Republic. E-mail: tomas.kostelecky@soc.cas.cz. 


\section{1. Úvod}

Při volbách do Poslanecké sněmovny parlamentu ${ }^{3}$ bylo území Česka vždy rozděleno na více volebních obvodů, ${ }^{4} \mathrm{v}$ nichž si voliči vybírali mezi kandidáty, kteři je chtěli v parlamentu zastupovat. Volební zákony také vždy upravovaly počty poslanců, kteří jsou $\mathrm{v}$ jednotlivých volebních obvodech voleni, a stanovovaly je $\mathrm{v}$ relaci $\mathrm{k}$ počtu obyvatel, resp. voličů účastnících se voleb $\mathrm{v}$ jednotlivých obvodech. Zvolení poslanci by tak mohli být považováni za politické reprezentanty občanů žijících $\mathrm{v}$ daném volebním obvodu. I přes tuto skutečnost však nelze parlament považovat za geograficky reprezentativní, a to ani v období 1918-1938 ani po roce 1989. Místo, odkud poslanec pochází, prípadně místo, kde má trvalé bydliště, není pro jeho práci v parlamentu rozhodující. Současní poslanci totiž jen $\mathrm{v}$ malé míře reprezentují volební obvody, spíš reprezentují ideologii strany, za kterou byli zvoleni. Přesto má smysl studovat prostorové rozložení místa původu, resp. bydliště poslanců a jejich změny v čase, protože nám tyto atributy geografické reprezentativity naznačují mnohé o fungování politického systému a systému zastupitelské demokracie v zemi.

Cílem tohoto článku je analyzovat a porovnat geografickou reprezentativitu českého parlamentu za první republiky s geografickou reprezentativitou parlamentu po roce 1989. Analýza se týká čtyř voleb do Poslanecké sněmovny Národního shromáždění republiky Československé (v letech 1920, 1925, 1929, 1935) a sedmi postkomunistických voleb, konkrétně voleb do České národní rady $\left(\mathrm{v}\right.$ roce $\left.1992^{5}\right)$ a Poslanecké sněmovny Parlamentu ČR (v letech 1996, 1998, 2002, 2006, 2010, 2013). V analýzách jsme se nezabývali obdobím mezi lety 1945 až 1992. V př́padě prvních poválečných voleb v roce 1946 se konaly jen částečně svobodné parlamentní volby a mezi lety 1948-1989 již o svobodných demokratických volbách nelze hovořit vůbec. Záměrně jsme vynechali i volby konané v roce 1990, necelý rok po sametové revoluci, nebot' tyto volby byly $\mathrm{v}$ mnohém specifické. Jednalo se spíše o referendum o komunistickém režimu než o klasické multistranické kompetitivní volby. Vzhledem k tehdejší „porevoluční“ situaci byl velmi specifický i samotný způsob výběru kandidátů na kandidátní listiny.

\footnotetext{
3 Ačkoliv se studie nezabývá volbami do Senátu, ale jen volbami do Poslanecké sněmovny, budeme pro jednoduchost v textu používat termín volby do parlamentu, resp. parlamentní volby. ${ }^{4}$ V letech 1990-1992 nemělo federální Československo horní a dolní komoru parlamentu, tedy Poslaneckou sněmovnu a Senát, nýbrž Federální shromáždění a národní rady. I do Federálního shromáždění a národních rad se poslanci volili ve volebních obvodech.

5 Pro analýzu roku 1992 jsme místo dat o poslancích Federálního shromáždění použili data o poslancích České národní rady, nebot' diskuse o uspořádání česko-slovenských vztahů v rámci federace vedly k posílení národních rad a politické marginalizaci Federálního shromáždění (Kostelecký et al. 2014), takže většina českých politických špiček té doby už ve volbách v roce 1992 kandidovala do České národní rady.
} 
Poslanci pocházející z hlavního města a $z$ regionů s výraznější identitou mají podle některých výzkumů (Latner a McGann 2005) větší zastoupení v parlamentu oproti poslancům pocházejícím z jiných regionů. Kandidáti pocházející z Prahy dominovali i prvním polistopadovým volbám v roce 1990. Jakým způsobem se zastoupení jednotlivých regionů $\mathrm{v}$ parlamentu vyvijelo $\mathrm{v}$ dalších letech je již předmětem naší analýzy. Výsledky jsme srovnali s geografickou reprezentativitou poslanců zasedajících v prvorepublikovém parlamentu, nebot' nás zajímalo, zda svobodné demokratické volby, konané v obou sledovaných historických obdobích, vykazují v tomto ohledu nějaké podobné rysy.

$\mathrm{V}$ první části článku se věnujeme pojmům reprezentace a reprezentativita, s hlavním důrazem na geografickou reprezentaci a její význam. Podrobně se zabýváme též vztahem mezi místem, odkud pochází kandidát, a jeho voličem. Následující kapitola se zaměřuje $\mathrm{v}$ obecné rovině na srovnání základních charakteristik voleb za první republiky a voleb po roce 1989, přičemž důraz klademe především na členění republiky na volební obvody a na stabilitu personálního složení parlamentu. Analýzou geografické reprezentativity parlamentu v obou sledovaných obdobích se podrobně zabývají sekce 4 a 5 . Na základě dat z Archivu Poslanecké sněmovny a ČSÚ je zkoumána nejprve geografická reprezentativita v členění za okresy, pak za celé kraje. V poslední části se věnujeme složení poslanců podle velikostní kategorie obcí, v nichž bydlí. V závěru diskutujeme možné prríčiny změn geografické reprezentativity.

\section{Reprezentace a reprezentativita ${ }^{6}$}

Volební právo, které vychází ze základní premisy moderní reprezentativní demokracie, představuje nejen právo na politickou participaci, ale také právo být v politice reprezentován. Volení zástupci jednají v zájmu občanů, ale nikoli jako jejich zmocněnci (Dahl 1973), a právě vztah mezi volenými zástupci a voliči patř́ $\mathrm{k}$ často diskutovaným tématům moderní politické vědy i demokratické teorie (Eulau et at. 1959; Pitkin 1967; Weissberg 1978; Mansbridge 2003). Politická reprezentace bývá definována různými způsoby a v různých kontextech. Jednou z nejvíce užívaných je pojetí Hannah Pitkin (1967), která vychází z etymologie termínu re-prezentovat neboli „učinit znovu přítomným něco, co není prítomno doslova nebo ve skutečnosti“, a politickou reprezentaci chápe jako aktivitu, která umožňuje prítomnost hlasů, názorů a postojů občanů v politickém procesu. Volení zástupci musí jednat tak, aby zajistili schopnost voličů pověřit volené

\footnotetext{
${ }^{6}$ Reprezentativita je definována jako schopnost dát ve voleném orgánu prostor různým zájmům, skupinám a stranám (viz Novák 1997). Lze ji charakterizovat jako indikátor toho, nakolik je ve voleném orgánu zastoupení poslanců podle různých hledisek reprezentativní. Reprezentativita je tedy spíše charakteristika zvoleného orgánu (v našem př́padě parlamentu), resp. souboru poslanců jako celku. Geografická reprezentativita charakterizuje, jak dalece je uplatněn princip geografické reprezentace mezi volenými poslanci.
} 
zástupce, umožnili voličům kontrolu volených zástupců a zároveň tak, aby si udrželi kapacitu jednat nezávisle na přáních voličů (Pitkin 1967). Pojetí principu zastoupení v politice se vyvíjelo od počátečního důrazu na geografické zastoupení, které bylo spojené zejména s majetkovým principem (zastupitel coby reprezentant vlastníků pozemků), k ideologickému pojetí spojovanému s teorií cleavages, kdy představitelé politických stran reprezentují určitou ideologii a zájmy dané tř́dy (Squires 1999). Vstup zájmových skupin a organizací občanské společnosti do politické arény ale i další vlivy jako evropská integrace znovu oživily diskusi o funkčnosti a roli politické reprezentace (Mansbridge 2003; Urbinati a Warren 2008; Pollak et al 2009; Brim a Dufek 2012), což vyústilo v nové př́ístupy k jejímu chápání a snahu o překonání klasického pojetí $H$. Pitkin vytvořením diferencovanějších a dynamičtějších modelů. Pitkin podle svých kritiků nedefinuje způsob, jakým je možné identifikovat „objektivni““ zájmy voličů, a neřeší tak paradox dualistického pojetí reprezentace ve vztahu mezi voličem a jeho zástupcem.

Cílem článku však není podrobné zkoumání politické reprezentace $\mathrm{z}$ teoretického hlediska a $\mathrm{v}$ této sekci nám jde především o představení základních př́stupů $\mathrm{k}$ danému tématu. Proto i nadále vycházíme ze zavedeného pojetí Hannah Pitkin, jež v knize The Concept of Representation (1967) představila typologii odlišující čtyři základní typy politické reprezentace: 1. formální reprezentaci (zástupce ze zákona jedná jménem voličủ, což je ovlivněno způsobem získání mandátu a statusem); 2. symbolickou reprezentaci vycházející z významu, který představuje zastupitel pro reprezentované; 3. deskriptivní reprezentaci (míra, s níž se volený zástupce podobá těm, které zastupuje - např. sociální tř́ída, pohlaví, etnická př́slušnost) a 4. substantivní reprezentaci. Substantivní reprezentace se týká toho, čím volený zástupce je, ale i toho, co dělá. Samotná deskriptivní reprezentace totiž nezaručuje, že zastupitelé podobní svým voličům budou skutečně hájit jejich zájmy, nicméně může do jisté míry být nástrojem, jehož prostřednictvím je pravděpodobnost substantivní reprezentace zvyšována. Stěžejní ovšem zůstává substantivní reprezentace, která klade důraz na reálné jednání politiků a soustředí se na to, jestli zastupující bude opravdu reprezentovat zájmy voličů.

Geografická reprezentace je součástí deskriptivní reprezentace. Deskriptivní reprezentace znamená, že zastupitel je svou osobou nebo životními zkušenostmi v určitém smyslu typickým představitelem širší skupiny lidí, které reprezentuje, a proto se očekává, že bude při vykonávání mandátu schopen dobře hájit jejich zájmy (Linek 2009; Poláková a Kostelecký 2016). Geografická reprezentace vychází z tradiční vazby mezi poslancem a jeho voliči v parlamentních systémech používajících většinový systém a jednomandátové volební obvody. Takový vztah ale existuje i varlamentních demokraciích používajících ve volbách systém poměrného zastoupení s přidělováním mandátů ve volebních obvodech. Každý volební obvod, který je geograficky vymezen, má v zastupitelském orgánu svého 
zástupce nebo více zástupců. Volební obvod a v něm žijící voliči, které každý zastupitel zvolený v tomto obvodu reprezentuje, ale zároveň vytvář́ kontext, prostor pro sociální interakce, které strukturují př́ležitosti (Agnew 1987; Johnston 1991). Různé typy míst jsou spojené s různým způsobem života, identitou, politickou kulturou i ekonomickými zájmy. Zástupci, kteří z daného místa pocházejí, tak mohou sdílet se svými voliči zkušenosti a náhled na některé problémy vycházející z daného kontextu.

Vzhledem k tomu, že každý volební obvod má na základě volebního zákona vlastního zástupce nebo více zástupců $\mathrm{v}$ zastupitelském orgánu, je určitá míra geografické reprezentace dopředu zaručena. Geografická reprezentace má proto ve většině zemí přednost před dalšími formami deskriptivní reprezentace, jako nap̌r. reprezentace etnické př́slušnosti, genderu, či sociální třídy. Výsadní postavení geografické reprezentace má své kritiky i zastánce. Podle některých (např. Lee 2007) geograficky vymezené volební okrsky spíše reflektují situaci v době, kdy existovaly izolované, zemědělské komunity, komunikace a cestování byly obtížné a volení představitelé zastupovali lokální zájmy. Nyní, v době moderních komunikačních a informačních technologií, jsou pro vyjádření a prosazování politických hodnot občanů důležitější politické strany a další institucionální $\mathrm{i}$ individuální aktérí. Vedle volených zástupců jsou na politické scéně též velmi aktivní různé zájmové skupiny a organizace občanské společnosti. S proměňujícím se politickým prostředím se tak postupně stírá hranice mezi formální a neformální reprezentací (Rakušanová Guasti 2009b).

Další z námitek proti přetrvávajícímu výsadnímu postavení deskriptivní geografické reprezentace spočívá v tvrzení, že voliči vymezení určitým volebním okrskem mají nyní málo společného a celkově se jedná o velmi heterogenní skupinu ve smyslu ekonomických zájmů, náboženství, rasy, třídy, etnicity, urbanizace atd. (Lee 2007). Na druhou stranu geograficky vymezené území není pouhou sumou svých částí, ale seskupením individuí, která jsou ovlivněna určitým prostorovým kontextem, který vede $\mathrm{k}$ sociálním interakcím, jež ovlivňuje př́ležitosti jednotlivců (Gimpel 2011; Johnston et al 2007). Řada politicky relevantních jevů a událostí je prostorově vázaná jako např. aktivita stranických buněk, průběh volební kampaně na určitém místě, z daného místa může pocházet významný kandidát (Bernard, Kostelecký 2014). Prostorový kontext má vliv i na socializaci voličů. Výzkumy ukázaly, že lokální sociální sítě ovlivňují volební chování jednotlivců, přičemž mají převážně homogenizační efekt (Kostelecký a Čermák 2004; Johnston et al 2007; Malcová 2012). V tomto kontextu se hovoří o tzv. „sousedském efektu“ (v angličtině zpravidla označovaném jako „neighbourhood effect“, méně často jako „contagion effect), který je definován jako jeden z typů kontextuálních efektů spočívající ve skutečnosti, že lokální sociální prostředí, v němž člověk žije, ovlivňuje způsoby, jakými uvažuje a jedná (Gregory et al. 2009: 495). 
Ačkoli si mnozí uvědomují, že geografická reprezentace má menší důležitost, než tomu bývalo v počátcích demokracie, většina autorů jí stále přisuzuje význam. Jedním z typických př́íladů přetrvávajícího významu geografické reprezentace je rozhodování o výdajích ze státního rozpočtu pro jednotlivé oblasti. ${ }^{7}$ Výzkumy ukazují, že jakákoli „podreprezentovaná“ oblast může být při distribuci veřejných peněz v území znevýhodněna (Latner a McGann 2005). Političtí reprezentanti regionu se snaží pro region získat určitý podíl ze státního rozpočtu, což je pro ně jedna z forem zviditelnění a svázání zastupitele s daným regionem a jeho voliči (Lee 2007; Hána 2013). Lokální politici zase naopak využívají známosti s politickými reprezentanty pocházejícími z kraje a působícími na národní úrovni k získávání informací, dotací a dalších výhod pro jimi spravovanou obec (Hána 2014). Druhým významným argumentem podtrhujícím význam geografické reprezentace je vazba politiků k určitému prostředí a zejména důvěrný vztah mezi voličem a kandidátem, který je založen právě na geografické blízkosti (Gimpel et al. 2008). Ohled na geografickou reprezentaci se pak promítá zejména do sestavování kandidátek jednotlivých politických stran.

Řada vědců tvrdí, že v současné době volby již nejsou volbami o lidech, které volič osobně zná, a proto se voliči príiklánějí z racionálních pohnutek k volbě politické strany, která je voliči blízká svým politickým programem (Downs 1957; Manin 1997). Zároveň se ovšem voliči rozhodují i podle toho, zda je jim kandidát blízký z geografického hlediska, zda pochází ze stejného regionu, v němž usiluje o hlasy, ačkoliv to není požadováno zákonem. ${ }^{8}$ Pro většinu kandidátů platí, že jejich volební podpora se snižuje spolu s rostoucí vzdáleností mezi bydlištěm kandidáta a místem, kde bydlí volič. Tento tzv. „efekt kandidáta“ funguje proto, že informace o jeho reputaci a důvěryhodnosti ztrácí svou sílu nebo zcela mizí s rostoucí vzdáleností (Johnston et al. 2005; Gimpel 2008; Voda 2009). Jako první tento efekt potvrdil ve své práci na základě analýzy voleb v jižních státech USA politolog Valdimer Orlando Key (1949). Key sám používal pro sledovaný jev název „,friends-and-neighbors effect“. Dictionary of Human Geography (Gregory et al. 2009: 264) tento jev definuje jako „formu kontextuálního efektu identifikovanou volební geografií spočívající ve skutečnosti, že voliči favorizují lokální kandidáty (dokonce i když to znamená opuštění jejich tradičních stranických preferencî), protože kandidáta osobně znají nebo věří, že jeho/její zvolení podpoří lokální zájmy“.

\footnotetext{
$7 \mathrm{~V}$ anglosaské literatuře se hovoří o tzv. pork barrel politics, v českém politickém slangu „porcování medvěda“.

8 Např. v USA musí být kandidát do Sněmovny reprezentantů a do Senátu obyvatelem státu, za který kandiduje. Volební zákon v ČR ani zákony v dalších evropských zemích (Velká Británie, Nizozemsko, Polsko) nepožadují, aby kandidát pocházel z daného volebního obvodu. Různá pravidla však mohou fungovat $\mathrm{v}$ politických stranách, které kandidáty do voleb vybírají. Tématu navrhování a výběru kandidátů v jednotlivých politických stranách v ČR se věnují Outlý, Prouza a kol. (2013).
} 
V českém prostř́edí neexistuje jednotný pohled na to, jak překládat „friendsand-neighbors effect" do češtiny". V našem textu se budeme držet spíše politologické tradice a používat termín efekt kandidáta, budeme ho ovšem chápat v užším slova smyslu, který hledí primárně na kandidátovo bydliště a jeho vliv na prostorové rozložení jeho volební podpory.

Existence efektu kandidáta ukazuje, že přinejmenším někteří voliči favorizují místního kandidáta. Voda a Pink (2009) na základě analýzy kandidátních listin ve volbách do Poslanecké sněmovny v roce 2006 však zjistili, že pro celkovou výši podpory kandidáta ve volebním obvodu nemusí být bydliště kandidáta prúliš podstatné. $\mathrm{V}$ př́padě stranických lídrů s bydlištěm mimo daný volební obvod se nemusí lišit výše jejich osobní podpory od podpory místních kandidátů ve volebním obvodu, odlišné je ale její prostorové rozmístění. Zatímco domácí kandidáti mají svoji podporu koncentrovanou okolo svého místa bydliště, „importovaní“ lídři mají poměrně homogenní podporu na území celého volebního obvodu, jejíž výše závisí především na tom, o jak známé osobnosti jde (Voda a Pink 2009).

Ve stranách funguje při sestavování kandidátek vnitřní politická soutěž a zároveň pro stranu je výhodné postavit kandidáty z různých regionů kvůli identifikaci voličů s lokálními kandidáty. Takže i v př́ípadech, kdy nejsou žádné institucionální tlaky na to, aby byli kandidáti reprezentanty regionů či měst, volební soutěž vytváří tlak na regionálně vyvážené kandidátky (Latner a McGann 2005). Kandidatura lokální osobnosti ve volbách má navíc potenciál zvýšit volební účast obyvatel př́slušné lokality a může přivést $\mathrm{k}$ volbám $i$ takové voliče, kteří se voleb běžně neúčastní (Gimpel 2008; Malcová 2012).

Proporční volební systémy, v nichž kandiduje velký počet kandidátů bud' v celé zemi jako jednom volebním obvodu nebo ve větším počtu, zpravidla prostorově rozsáhlých, volebních obvodů, samy o sobě nijak nezajišstujuí geografickou reprezentativitu zvolených poslanců a není jasné, jaká je skutečná geografická reprezentativita kandidátů, resp. zvolených poslanců. Přesto je v zemích, kde se proporční volební systémy používají, možné odhalit určité prostorové vzorce reprezentativity.

\footnotetext{
9 Voda (2009) a Voda a Pink (2009) překládají původní anglický termín jako „efekt kandidáta“ a chápou ho primárně jako vliv místa bydliště kandidáta na jeho volební výsledky, především počty preferenčních hlasů. V pozdějších pracích používal Petr Voda $(2010,2013,2014)$ i nadále termín „efekt kandidáta“, ale chápal jej už šíreji, jako vliv různých osobních charakteristik kandidáta na jeho podporu mezi voliči, přičemž bydliště či působiště kandidáta bylo jen jedním z takových atributů, které zvyšovaly šanci, že budou podporováni určitými voliči. Karolína Malcová (2012) ve své analýze vlivu místa bydliště kandidátů na jejich podporu voliči při volbách do Senátu překládá „friends-and-neighbors effect“ s odkazem na starší české práce z počátku 90. let (Kostelecký 1993: 171-172) jako „sousedský efekt“, sama však tento překlad nepovažuje za ideální a za vhodnější považuje spíše označení „efekt sousedů“ nebo „efekt přátelstvi““ (Malcová 2012: 285).
} 
Jedním z mála príklado̊, kdy byla tato problematika geografické reprezentativity parlamentu empiricky zkoumána, je práce Latnera a McGanna (2005), kteří na prípadě Izraele a Nizozemska poukázali na to, že hlavní město, ale i periferní regiony a regiony s výraznější identitou mají v parlamentu více zvolených zástupců než regiony přilehlé k hlavnímu městu.

\section{Volby v Česku}

Volby v Česku v letech 1918-1938 a po roce 1990 jsou si v mnohém podobné, protože navázat na tradici první republiky bylo i jedním z cílů autorů volebního systému po roce 1989. Při volbách do Poslanecké sněmovny Národního shromáždění v letech 1920-1935 byl stejně jako ve volbách po roce 1990 použit systém poměrného zastoupení, $v$ němž si volič vybírá z kandidátních listin, které předkládají politické strany. Mandáty pro jednotlivé kandidáty, resp. strany, jsou pak přidělovány na základě počtu získaných hlasů. Strany s vyšší mírou podpory mezi voliči získají proporcionálně vyšší podíl parlamentních křesel a naopak. K určitému omezení principu proporcionality došlo po roce $1990,{ }^{10}$ kdy bylo zavedeno tzv. $5 \%$ kvórum pro vstup do prvního skrutinia, které z rozdělování mandátů vylučovalo strany, jež v celostátním průměru nezískaly alespoň $5 \%$ odevzdaných hlasů. To významně omezilo počet stran $\mathrm{v}$ parlamentu. Zatímco za první republiky, kdy žádné legální kvórum neexistovalo, se do sněmovny běžně dostalo 15 až 16 stran, po roce 1990, jich bylo maximálně 8. Za první republiky, na rozdíl od volebního systému po roce 1990 existovala volební povinnost a fungovaly př́sně vázané kandidátky, což znamená, že neexistovala možnost preferenčního hlasování a volič tak o konkrétním personálním složení sněmovny rozhodoval pouze prostřednictvím volby strany (Broklová 1992; Chytilek et al. 2005).

Česko bylo za první republiky rozděleno na 14 volebních krajů, které se však svým územním vymezením neshodují s dnešními kraji (Kostelecký a kol. 2014). Po roce 1990 existovalo v Česku osm volebních obvodů odpovídajících administrativním krajům $z$ let 1960-1990, od voleb v roce 2002 se volí ve 14 volebních obvodech, které jsou totožné s vyššími územně samosprávnými celky, kraji, vytvořenými v roce 2000. Prvorepubliková Poslanecká sněmovna Národního shromáždění měla 300 poslanců, 230 z nich zastupovalo české země. ${ }^{11}$ Česká národní rada měla 200 poslanců, stejný počet poslanců má i z ní po rozdělení Československa vzniklá Poslanecká sněmovna Parlamentu ČR. Další rozdíl mezi prvorepublikovými a současnými volbami je ve způsobu stanovení počtu mandátů pro jednotlivé volební obvody. Zatímco za první republiky počet

\footnotetext{
${ }^{10} \mathrm{Na}$ základě \42, odst. 1, zákona 54/1990 Sb. o volbách do ČNR platného od 6.3.1990.

11 Ve volbách v roce 1920 bylo přiděleno kvůli nekonání voleb na tzv. plebiscitních územích celkem pouze 281 poslaneckých mandátů (Chytilek et al. 2009).
} 
volených poslanců pro jednotlivé volební obvody odrážel počet jejich obyvatel a byl předem stanoven, ${ }^{12}$ od roku 1990 se při přidělování mandátů jednotlivým volebním obvodům vychází z počtu voličů, kteř́ se zúčastní voleb. Před volbami tak není známo přesné rozdělení počtu mandátů jednotlivým obvodům. Počty mandátů přidělovaných jednotlivým obvodům $\mathrm{v}$ různých volebních obdobích se však nemění nijak významně. Za první republiky se počet mandátů v krajích změnil v roce 1925, kdy se volební obvod Těšín stal součástí Moravské Ostravy, a mandáty byly přerozděleny ve prospěch velkých měst. Po roce 1989 počet mandátů v několika volebních obvodech klesl (např. v Západočeském nebo v Severočeském kraji, později v Praze), naopak do roku 1998 vzrostl počet přidělovaných mandátů ve Východočeském a Jihomoravském kraji. Po volbách v roce 2002 vzrostl počet mandátů pouze ve Středočeském kraji, který je jediným krajem, jehož počet obyvatel (a tím i voličů) od roku 1997 stabilně roste a kde zároveň volební účast převyšuje republikový průměr.

Jedním z významných rysů parlamentu je relativně velká stabilita jeho personálního složení, a to v obou sledovaných obdobích. V letech 1920-1935 bylo vysoké procento poslanců zvoleno do sněmovny více než dvakrát. 45 z celkových 230 prvorepublikových českých poslanců dokonce zastávalo poslanecký mandát po celé období od roku 1920 až po volby v roce 1935. Více než polovině poslanců se opakovaně dařilo obhajovat svůj mandát, jen v roce 1935 tento podíl mírně klesl. V ČNR a posléze v Poslanecké sněmovně v období 1990-2013, zahrnujícím sedm volebních cyklů, sice celkově převažovali poslanci, kteř́ získali mandát pouze jednou, avšak na druhou stranu jich bylo 166 zvoleno třikrát a vícekrát. ${ }^{13}$ Počet poslanců, kteři byli schopni ve volbách obhájit své mandáty, se zvyšoval až do roku 2002, kdy byla více než polovina poslanců opětovně volena do sněmovny. Od té doby tento podíl zejména kvưli vstupu nových stran do parlamentu klesá. I tak podíl poslanců, kteří v roce 2013 obhájili svůj poslanecký mandát, dosáhl téměř $40 \%$. (viz tabulka 1 a graf 1 ).

V obou historických obdobích mủžeme pozorovat podobný scénář vývoje: malou obměnu osobností, zpočátku nárůst počtu poslanců, kteří opakovaně obhajují svůj mandát, a následně jejich pokles. V tomto ohledu byly za první republiky zlomovými volby v roce 1935, po roce 1990 to byly volby v roce 2006. Rostoucí procento znovuzvolených poslanců svědčí podle Mansfeldové (2015) o pozitivním vývoji zákonodárného orgánu, nebot’ vede $\mathrm{k}$ jeho profesionalizaci a tím stabilitě. Obměna politických osobností může být někdy i politickými stranami cílená ve snaze přilákat nové voliče (např. KSČM v roce 2002). Vstup

\footnotetext{
12 Důvodem bylo zachování určité nerovnosti kvưli volební geometrii. V praxi byly zvýhodněny Čechy a Slovensko před Moravou a Slezskem a ty před Podkarpatskou Rusí (Chytilek et al. 2009).

13 Historicky nejčastěji voleným poslancem je Marek Benda, který byl poslancem ve všech volebních obdobích po roce 1989; jen po volbách v roce 2006 se dostal do parlamentu až jako náhradník uprostřed volebního období.
} 
nováčků do parlamentu však nemusí znamenat snížení věkového průměru poslanců, ten od roku 1990 naopak rostl (Mansfeldová 2015).

Tabulka 1. Poslanci podle počtu volebních období, ve kterých byli zvoleni do parlamentu (v letech 1920-1935 a 1990-2013)

\begin{tabular}{|c|c|c|c|c|}
\hline $\begin{array}{c}\text { Počet volebních } \\
\text { období, ve kterých } \\
\text { poslanec působil } \\
\text { v parlamentu }\end{array}$ & $\begin{array}{c}\text { Počet poslanců } \\
1920-1935\end{array}$ & $\%$ & $\begin{array}{c}\text { Počet poslanců } \\
1990-2013\end{array}$ & $\%$ \\
\hline 1 & 295 & 56,6 & 577 & 60,9 \\
\hline 2 & 103 & 19,8 & 204 & 21,5 \\
\hline 3 & 78 & 15,0 & 88 & 9,3 \\
\hline 4 & 45 & 8,6 & 50 & 5,3 \\
\hline 5 & & & 18 & 1,9 \\
\hline 6 & & & 9 & 1,0 \\
\hline 7 & & & 1 & 0,1 \\
\hline
\end{tabular}

Zdroj: vlastní výpočty podle ČSÚ

Graf 1. Podíl poslanců, kteří obhájili mandát ve volbách do Poslanecké sněmovny v letech 1925-1935 a 1992-2013

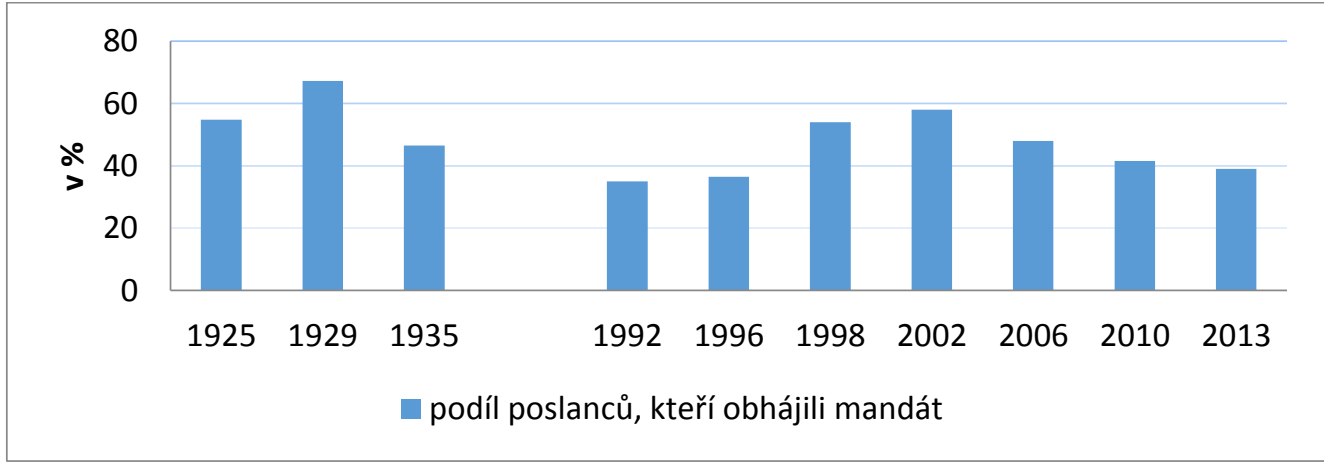

Zdroj: vlastní výpočty podle ČSÚ

Pozn.: v roce 1992 šlo o volby do České národní rady

Podle Ústavy ČR a podle klasické teorie reprezentace je mandát poslance koncipován jako mandát voleného zástupce všech občanůa a ne pouze jeho voličů. Praxe však bývá často odlišná. Je možné se setkat s různými pojetími mandátu, přičemž každé pojetí jiné než zastupování všech občanů je posunem od principu reprezentace $\mathrm{v}$ parlamentní demokracii k principu delegace, ve kterém je poslanec spojen s nějakým segmentem populace (Brokl et al. 2001). Roli poslance lze definovat různými způsoby: jako mandát vázaný svědomím (trustee), vázaný voliči 
(delegate), mandát oscilující mezi těmito dvěma pojetími (politico) či jako mandát vázaný stranou (Eulau, Karps 1977; Rakušanová Guasti 2009a). Z výzkumu českých poslanců v roce 2007 vyplynulo, že se cítí být zejména reprezentanty své strany a jejích voličů (Rakušanová Guasti 2009a). Oproti výzkumům prováděným v 90. letech (Brokl et al. 2001) narostl podíl těch, kteří vnímali mandát ve smyslu zastupitelském, tedy ve smyslu odpovědnosti vůči voličům jejich volebního obvodu; stranická identifikace však představovala dominantní faktor jejich rozhodování (Brokl et al. 2001; Rakušanová Guasti 2009a). Pojetí mandátu ze strany poslanců je podle Brokla ovlivněno zejména organizační strukturou jejich politické strany. Poslanci strany se silnější organizační strukturou spojovali svou odpovědnost spíše s voliči strany, poslanci strany se slabší organizační strukturou spíše s občany svého volebního obvodu či prímo se všemi občany (Brokl et al. 2001).

\section{Geografická reprezentativita poslanců}

Při analýze geografické reprezentativity poslanců nás zajímá místo bydliště poslanců. V prrípadě voleb po roce 1989 vycházíme př́i určení místa bydliště poslanců z údajů, které zvolení poslanci ještě coby kandidáti uvedli jako místo svého trvalého bydlišstě na kandidátce. $\mathrm{V}$ případě prvorepublikových voleb jsme takové informace $\mathrm{k}$ dispozici neměli, vycházeli jsme proto $\mathrm{z}$ údajů ze stenoprotokolů a zápisů ze schůzí uložených ve Společné česko-slovenské digitální parlamentní knihovně, v nichž bylo bydliště poslance uváděno. Ve všech př́padech jsme konkrétní místo bydliště poslance přiřadili k současnému okresu, ve kterém se uvedené místo nachází. $V$ dalších analýzách již pracujeme pouze s údaji o bydlištích poslanců v členění za jednotlivé okresy. Personální složení parlamentu v obou historických obdobích před druhou světovou válkou i po roce 1989 se během volebních období proměňovalo nap̌r. kvůli odstoupení nebo odvolání poslance. Změny v období mezi volbami měly mnoho různých prúćcin, často i nepolitických (nemoc, úmrtí poslance). Př́i srovnání geografické reprezentativity zvolených poslanců jsme proto vycházeli z personálního složení Poslanecké sněmovny $\mathrm{v}$ den voleb a $\mathrm{k}$ prípadným pozdějším změnám už nepřihlíželi.

Pro analýzu geografické reprezentativity českých poslanců jsme využili metodu Latnera a McGanna (2005), kteří ji vyjadřovali za pomoci ukazatele zvaného míra proporcionality (proportionality ratio) vypočítaného jako podíl relativního počtu poslanců s bydlištěm $\mathrm{v}$ daném okrese a relativního počtu obyvatel $\mathrm{v}$ daném okrese. ${ }^{14}$ Jestliže míra proporcionality v okrese dosahuje právě hodnoty 1 , obyvatelé okresu jsou v parlamentu zastoupeni proporcionálně jejich

14 Míra proporcionality $=$ (počet poslanců s bydlištěm v okrese/počet poslanců sněmovny) $/$ (počet obyvatel okresu/počet obyvatel ČR) 
počtu. Čím je míra proporcionality nižší, tím jsou obyvatelé okresu v parlamentu méně zastoupeni, a naopak hodnoty nad 1 znamenají nadreprezentovanost populace okresu v parlamentu. Srovnávali jsme míry proporcionality poslanců za volby v letech 1920,1925, 1929 a 1935 a za v období po roce 1989 za volby v letech 1992, 1996, 1998, 2002, 2006, 2010 a 2013. Za jednotku analýzy jsme použili okresy, $v$ jejich dnešním vymezení, jako jednotky administrativního členění státu. V tomto prípadě se okresy jeví jako nejlepší prostorové jednotky kvưli jejich počtu (76 + Praha jako zvláštní jednotka) i velikosti. Údaje o bydlišti zvolených poslanců jsme ve všech př́padech lokalizovali na úrovni obce a přiřadili ji ke konkrétnímu okresu. Prostorově menší jednotky, např. prvorepublikové soudní okresy nebo správní obvody obcí s rozšířenou působností (ORP) považujeme pro naši analýzu za nevhodné vzhledem $\mathrm{k}$ tomu, že jich je př́liš velký počet, a tedy nutně musí existovat velký počet jednotek s nulovým zastoupením v parlamentu.

Celkově je míra proporcionality u prvorepublikových voleb nižší než $\mathrm{v}$ př́padě voleb uskutečněných po roce 1989. Pro prvorepublikové volby jsou charakteristické velké rozdíly v geografické reprezentativitě parlamentu (viz obrázek 1). $\mathrm{Na}$ jedné straně byly významně nadreprezentovány okresy, v nichž ležela v té době nejvýznamnější města (především Praha, Brno, Plzeň, Liberec), ${ }^{15}$ a na druhé straně byli ve sněmovně jen málo zastoupeni poslanci z venkovských okresů, zejména těch výrazně zemědělských. Jeden ze současných okresů, Rakovník, neměl dokonce po celé prvorepublikové období ve sněmovně nikdy žádné zastoupení. Téměř polovina okresů dosahuje hodnot míry proporcionality 0,5 a nižších. Obecně lze říci, že nadreprezentovaných bylo pouze 11 ze 77 okresů. Mezi tyto okresy patři vedle Prahy, Brna a Plzně převážně urbanizované okresy a často také okresy, kde v období první republiky převažovalo obyvatelstvo německé národnosti. Dominantní postavení velkých měst může být vysvětleno historickým vývojem. Česká politická elita byla v rakouském mocnářství po dlouhou dobu potlačována, a tudíž málo početná. Vznikající české politické strany byly spojeny s existencí úzké skupiny politických elit, které se soustřed'ovaly zejména ve velkých městech (Broklová 1992). Vyšší míra proporcionality v okresech s vysokým podílem německého obyvatelstva souvisí s tím, že za první republiky fungovaly vedle sebe dva stranické systémy. České politické strany získávaly podporu jen $\mathrm{v}$ „českých“"16 okresech a německé strany pouze v „německých“ (Kostelecký et al. 2014), které se nacházely zejména v pohraničních oblastech. Okresům s největšími městy s výjimkou Liberce dominovalo české obyvatelstvo.

\footnotetext{
15 Proporcionalita v př́pady Prahy byla 4,24, v případě Brna 3,02, Plzně 2,31 a Liberce 1,59.

16 „Ceskými“ okresy nazýváme okresy, kde dominovalo obyvatelstvo české národnosti, $\mathrm{v}$ „německých“ okresech dominovalo obyvatelstvo německé národnosti.
} 
Obrázek 1: Míra proporcionality $\mathrm{v}$ zastoupení okresů $\mathrm{v}$ Poslanecké sněmovně Národního shromáždění (průměr v letech 1920, 1925, 1929 a 1935)

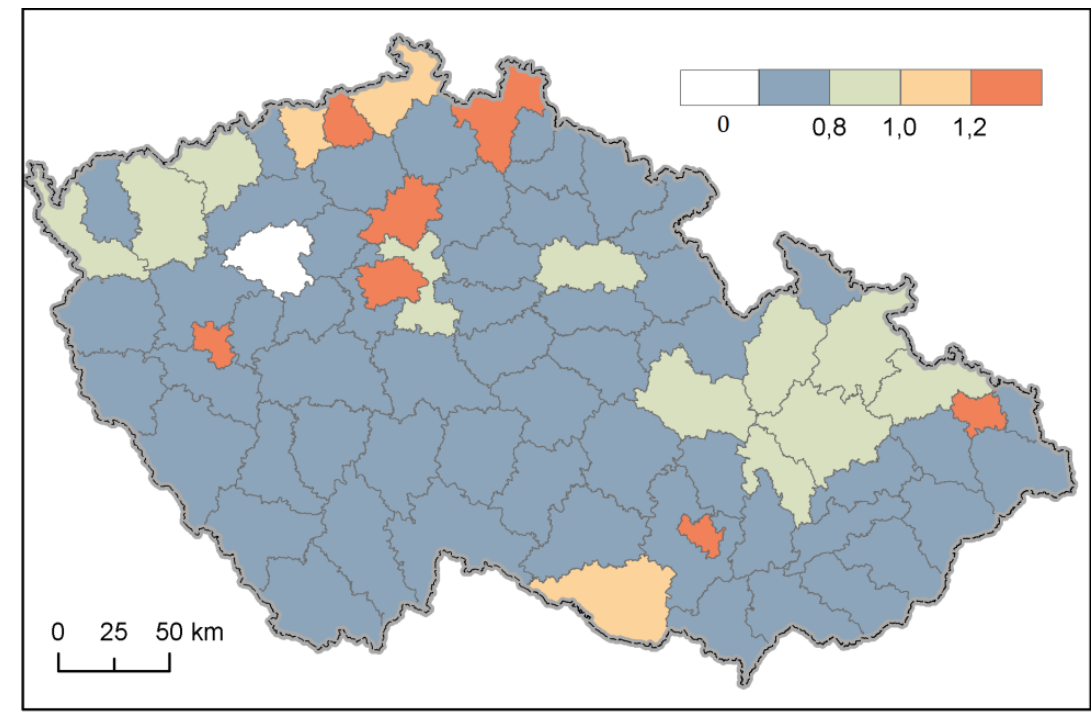

Zdroj: vlastní výpočty na základě dat ČSÚ

Po vzniku samostatného Československa v roce 1918 zastávalo ještě dva roky funkci parlamentu nově vzniklé tzv. Revoluční národní shromáždění, ve kterém působili poslanci zvolení do Poslanecké sněmovny rakousko-uherské říšské rady $\mathrm{v}$ roce 1911. Teprve v roce 1920 se uskutečnily první volby, v nichž ovšem měli značnou výhodu poslanci, kteři už působili v Revolučním národním shromáždění (Broklová 1992). Pozici stranickopolitických elit první republiky do značné míry posilovala použitá forma poměrného volebního systému, jehož součástí byl systém př́sně vázaných stranických kandidátek. To dávalo velkou moc úzkému vedení politických stran při sestavování kandidátek pro budoucí volby (Kárník 2000). Zákon navíc umožňoval, aby byl se souhlasem tzv. volebního soudu poslanec zbaven mandátu i po svém zvolení, „pokud ztratil po volbě volitelnost" (např. byl soudem zbaven práva volně nakládat se svým majetkem nebo byl odsouzen za trestný čin, pro který podle platných ustanovení nastala i ztráta volebního práva), nebo „přestal-li býti z důvodů nízkých a nečestných př́slušníkem strany, z jejíž kandidátní listiny byl zvolen“ (『 13 zákona 125/1920 Sb. o volebním soudě). V praxi se ukázalo, že volební soud interpretoval slova o „nízkých a nečestných“ důvodech pro vyloučení poslance ze strany dosti volně a ve prospěch politických stran. Poslanci vyloučení ze strany tak byli reálně zbavováni i mandátu, což ještě více posílilo moc stranických špiček. Vládní stranicko-politická elita byla poměrně úzkým okruhem lidí. Za celé období první republiky nedošlo $\mathrm{k}$ výměně generací (pouze $\mathrm{k}$ jejímu náznaku $\mathrm{v}$ posledních letech) a zejména na ministerských a premiérských křeslech zasedala generace, 
která zahájila politickou kariéru již v období habsburského mocnářství (Kárník 2000). Ve volbách v roce 1935 se do parlamentu prosadily výrazněji nové tváře, což souvisí s volebním úspěchem tehdy nově kandidující Sudetoněmecké strany. To se projevilo i ve změnách míry proporcionality, v nichž se zásadní rozdíly mezi největšími městy a dalšími okresy zmenšily.

Po roce 1989 byl historický kontext volby poslanců velmi odlišný. Poslanci, kteří byli zvoleni v prvních svobodných volbách po roce 1989, se z velké většiny rekrutovali z řad politických nováčkủ stejně jako další představitelé politické elity. V zásadě se neodehrála žádná masová reprodukce staré komunistické mocenské elity z „normalizačního“ období (1970-1989) (Tuček a kol. 2006; Machonin 2011). Nové osobnosti, které se po sametové revoluci staly novou politickou elitou, pocházely často z lidí aktivních v disidentském hnutí, včetně jejich exilových spojenců, z lidí perzekvovaných za komunismu nebo jejich potomků. Nejpočetnější skupinu tvořili lidé sociálně aktivní, vzdělaní a kvalifikovaní, jejichž ambice byly blokovány předchozím politickým systémem (Tuček a kol. 2006). V době prvních porevolučních voleb se poslanci do parlamentu dostávali nikoliv na kandidátkách politických stran, nebot' stranický systém nebyl ještě vyvinutý, ale spíše prostřednictvím hnutí, a to bez později obvyklých nominačních postupů (Brokl et al. 1998). Rekrutace poslanců, kteř́ se dostali do parlamentu ve volbách v roce 1992, již byla odlišná. Kandidáti byli vybíráni z členů nově vzniklých politických stran a z lidí, kteří se již nějakým zpưsobem podíleli na politické moci (byli nap̌r. členem nějakého reprezentativního orgánu či pocházeli ze státní administrativy na regionální úrovni). Kandidáti byli vybíráni nějakou formou nominačního procesu zdola, z regionů a okresů. Strany se $\mathrm{v}$ tomto základním principu nelišily; mezi politickými stranami existoval pouze rozdíl $\mathrm{v}$ tom, jak byla stanovena nominační pravidla, např. pro nominování kandidáta na první místo nebo procento žen na kandidátce (Brokl et al. 1998). Většina zvolených poslanců měla $\mathrm{v}$ počátečním období jen velmi málo politických zkušeností. $\mathrm{V}$ dalších letech významně rostl podíl poslanců, kteři získali své prvotní politické zkušenosti na komunální nebo krajské úrovni politiky (Mansfeldová 2015). Podíl těch, kteří získali prvotní politické zkušenosti až na parlamentní úrovni, klesal (ibid.).

Míra proporcionality ve volbách konaných po roce 1989 se oproti situaci za první republiky zvýšila, což dokládá větší rovnoměrnost geografické reprezentace poslanců. Podobně jako za první republiky byla zprvu (v letech 1992-1998) v Poslanecké sněmovně nejvíce zastoupena Praha, avšak rozhodně ne tak významně jako v př́padě první republiky (míra proporcionality 1,41). Následují ji okresy Domažlice a Pelhřimov, u nichž míra proporcionality přesáhla 1,2. Celkově se zvýšil na 23 počet okresů, jejichž míra proporcionality se pohybuje okolo jedné (míra proporcionality v rozmezí $0,8-1,2$ ), tedy hodnoty označující „dokonalou“ prostorovou reprezentativitu (za první republiky jich bylo 15). Ačkoli se celkově rozdíly $\mathrm{v}$ míře proporcionality mezi okresy zmenšily, stále existovaly okresy s nulovým zastoupením v parlamentu, a to Beroun, Mělník a Tachov. Právě 
Beroun společně s okresem Benešov $\mathrm{v}$ novém století významně zvýšil své zastoupení ve sněmovně, a to na úkor Prahy, u níž se míra proporcionality $\mathrm{v}$ dalších volbách stále snižovala.

V dalších čtyřech volbách (2002, 2006, 2010, 2013) byla geografická reprezentace okresů, jak je zachycena informací o místu trvalého bydliště kandidátů, ještě rovnoměrnější. Průměrná hodnota proporcionality dosáhla 0,95 oproti $0,65 \mathrm{v}$ předcházejícím období. Ve více než polovině okresů přesahuje míra proporcionality hodnotu 1 , avšak ve většině z nich jen mírně. Ve třech okresech byla míra proporcionality vyšší než 1,7 (Tábor, Jablonec nad Nisou a Náchod). ${ }^{17}$ Význam Prahy jako „zásobárny poslancư se stále snižoval. Místa, odkud se rekrutují poslanci, se přesouvají do regionů mimo největší města. K největším změnám mezi volbami vobdobích 1992-1998 a 2002-2013 došlo ve středočeských okresech Beroun, Benešov a Kutná Hora, což je zřejmě ovlivněno suburbanizačními procesy. Naopak největší pokles se projevil v okrese Rokycany, což je jediný okres, který v druhém sledovaném období neměl ve sněmovně ani jednoho zástupce. Mezi další okresy s největším poklesem patři Strakonice, Šumperk, Pelhřrimov a Praha.

Pokud analyzujeme odděleně pouze výsledky dvou posledních voleb (2010 a 2013), které byly do určité míry zlomové, nebot' se do parlamentu dostaly po dlouhém stabilním období nové politické strany a hnutí a s tím i řada zcela nových poslanců a poslankyň, ukáže se, že začíná docházet k mírné polarizaci. Na jedné straně se zvýšil počet okresů s nulovým zastoupením ve sněmovně ( 6 okresů) a na druhé straně se zvýšil počet okresů s proporcionalitou vyšší než 2 (4 okresy Tábor, Most, Benešov a Jablonec nad Nisou) (viz obrázek 2). Ve třech př́padech spolu sousedí okresy s velmi malým, a naopak s výrazným zastoupením v parlamentu, což může svědčit o tom, že pouze poslanci bydlí v nedalekém sousedním okrese a okresy jako prostorové jednotky nejsou v tomto př́padě pro analýzu ideální. Většina ostatních okresů se však pohybuje okolo optimální míry proporcionality (hodnota 1). Zajímavé však je to, že se mezi okresy s nejvyšší mírou proporcionality neobjevují žádné okresy, na jejichž území leží největší města. Hlavní město Praha zcela ztratilo dominanci, kterou mělo do té doby.

17 Okres Tábor dosáhl míry proporcionality 2,04 a jako jediný přesáhl hodnotu 2. 


\section{Obrázek 2: Míra proporcionality $\mathrm{v}$ zastoupení okresů Poslanecké sněmovně Parlamentu (průměr v letech 2010, 2013)}

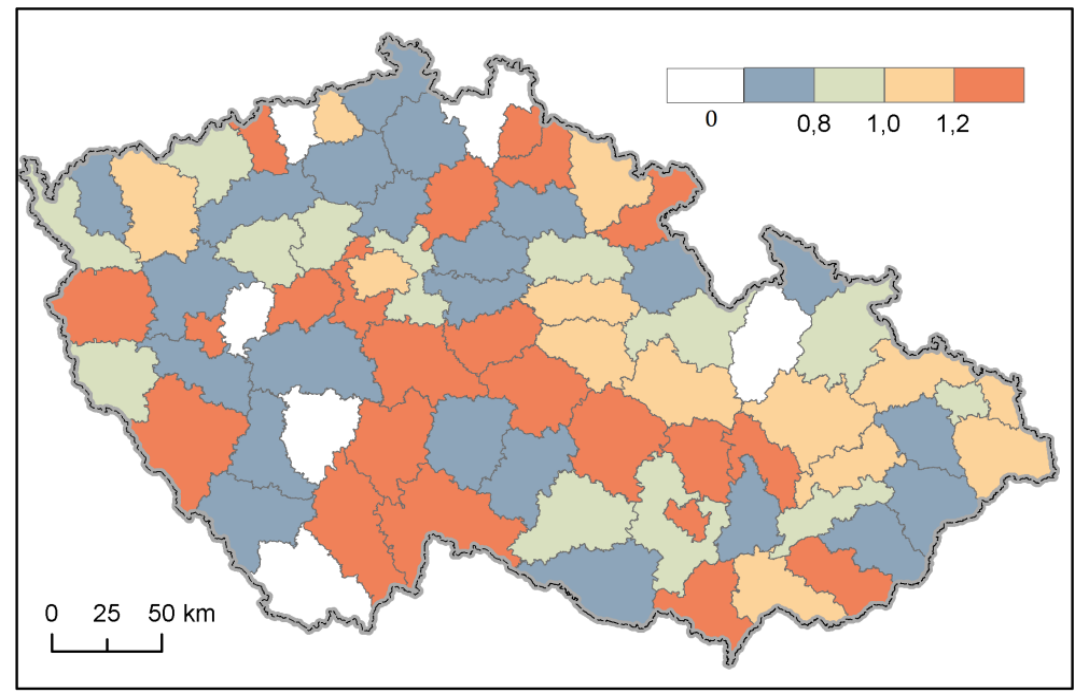

Zdroj: vlastní výpočty na zákaldě dat Čsú

$\mathrm{V}$ předchozí části textu jsme se zabývali geografickou reprezentací okresů, tedy relativně velkého počtu prostorově poměrně malých jednotek. V následující části se zaměříme na analýzu toho, jak se vyvijela geografická reprezentace krajů po roce 1989. Jako jednotku sledování jsme použili dnešní samosprávné kraje, které jsou od voleb v roce 2002 i volebními obvody. Je třeba upozornit, že v prvních čtyřech volbách po roce 1990 se používalo rozdělení na 8 volebních obvodů (totožných s původními administrativními kraji zrušenými v roce 1990). Při hodnocení míry proporcionality jsme mandáty zvolených poslanců přičlenili k současným krajům podle místa jejich trvalého bydliště. Graf 2 ukazuje míru proporcionality podle jednotlivých krajů a jejich změny mezi roky 1992 a 2013. Z grafu je především patrný zřetelný konvergenční trend - původně velké rozdíly v míre proporcionality mezi kraji se ve sledovaném období postupně zmenšily. $\mathrm{Na}$ počátku 90. let byli v Poslanecké sněmovně zřetelně nadreprezentováni poslanci s trvalým bydlištěm v Praze, kterých bylo dvakrát více, než by odpovídalo podílu obyvatel Prahy na celé populaci. Protože v Praze nebyl významně odlišný podíl obyvatel s volebním právem, ani se od ostatních krajů nijak významně nelišila volební účast, nemohla být nadreprezentovanost poslanců s bydlištěm v Praze způsobena tím, že by jich bylo ve volebním obvodu Praha zvoleno výrazně více, než by odpovídalo počtu obyvatel Prahy. Jediným možným vysvětlením tohoto nepoměru je skutečnost, že podstatná část poslanců $s$ bydlištěm v Praze byla zařazena na mimopražské kandidátky a zvolena $\mathrm{v}$ jiných volebních obvodech. Centrály politických stran tak „přidělily“ velký počet kandidátů pocházejících 
z Prahy do ostatních volebních obvodů. Naopak výrazně podreprezentované byly současný Karlovarský kraj a kraj Liberecký - poslanců v nich trvale bydlících bylo v některých volbách i méně než polovina, než by odpovídalo podílu těchto území na populaci České republiky. Zprvu jasná dominance poslanců bydlících v Praze se ovšem s postupem času dramaticky zmenšovala. Novela volebního zákona změnila vymezení volebních obvodů, takže už od roku 2002 se volební obvody shodovaly s dnešními samosprávnými kraji. Podle zákona mají kraje proporční zastoupení ve sněmovně na základě počtu voličů, kteří se zúčastnili voleb. Volební zákon však neurčuje, že kandidát musí mít trvalé bydliště ve volebním obvodě, takže rozptyl v hodnotách míry proporcionality mezi kraji přetrvával. Kandidátů, kteř́ by bydleli $\mathrm{v}$ jiném volebním obvodě, než kandidují, však rychle ubývalo. Od voleb v roce 2006 se proto míry proporcionality stabilizují v rozmezí 0,8 až 1,2 , tedy okolo čísla 1 , které představuje ideální proporcionální rozložení poslanců mezi volebními obvody.

Graf 2: Proporcionalita ve volbách po roce 1989 podle krajů

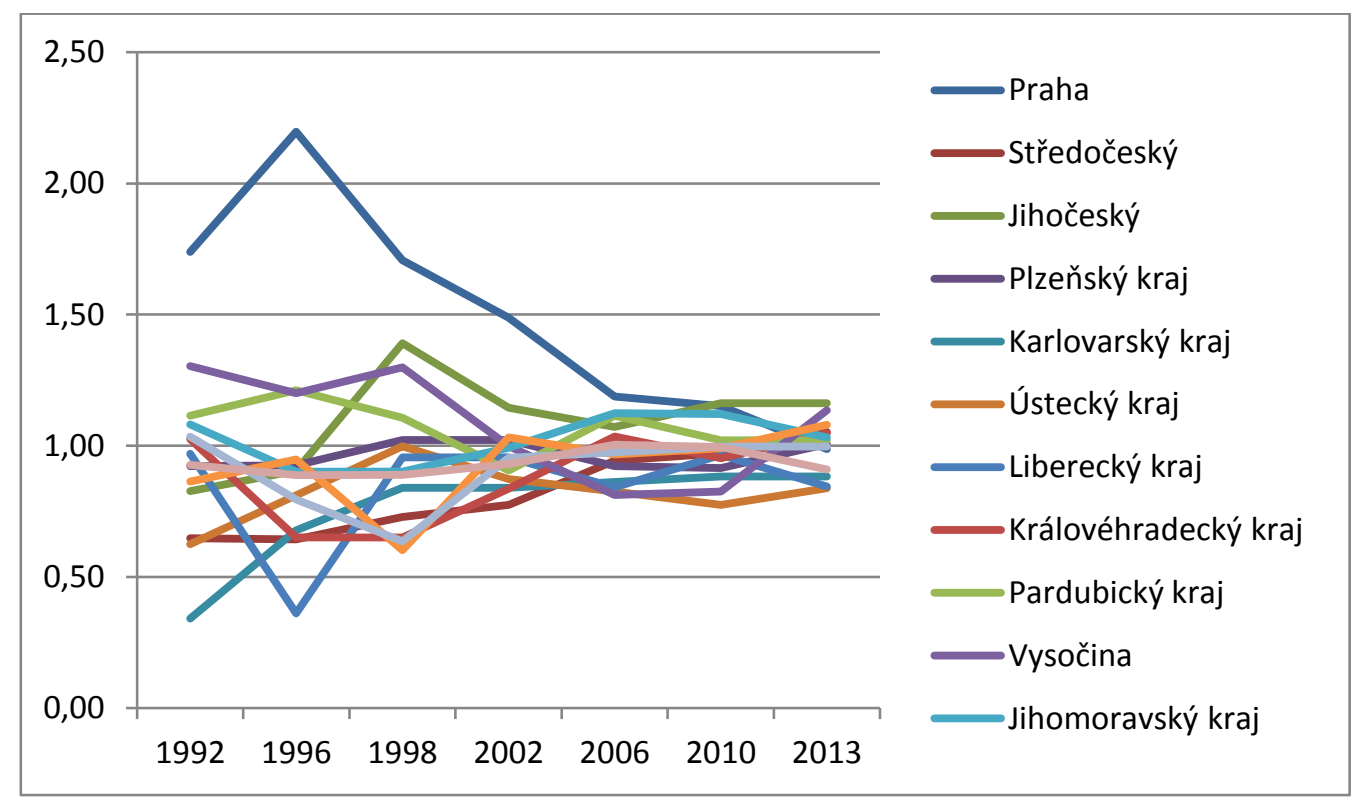

Zdroj: Vlastní výpočty na základě dat ČSÚ

\section{Reprezentativita podle velikostní kategorie obcí}

Důležitý je i pohled na strukturu poslanců českých parlamentů podle velikostní kategorie obcí, ve kterých mají zvolení poslanci trvalé bydliště. Zatímco počet obyvatel velkých měst a zejména Prahy za první republiky rostl, podíl poslanců se vyvíjel jinak. Podíl poslanců, kteří uváděli na kandidátkách před volbami jako své 
trvalé bydliště Prahu, se nejprve mírně zvyšoval, a to až do voleb v roce 1929. Od té doby, víceméně s jediným výkyvem v roce 1996, setrvale klesá. To je v rozporu s obecně vnímanou představou, že o všem se rozhoduje v Praze a že lidé z Prahy zaujímají většinu postů $\mathrm{v}$ parlamentu. V Brně, Ostravě a Plzni i v osmi dalších největších městech, ${ }^{18}$ která zhruba reprezentují ostatní krajská města, podíl počtu obyvatel za první republiky nerostl tak rychle jako v Praze a po roce 1989 dokonce mírně klesá (viz graf 3). Podíl počtu poslanců z těchto měst se vyvíjel odlišně za první republiky a po roce 1989 (viz graf 4). Zatímco za první republiky se zvyšovala váha politické reprezentace ze třech největších měst po Praze, a naopak klesal podíl poslanců z „krajských“ měst, po roce 1989 si kandidáti z obou těchto kategorií měst s určitými výkyvy udržují své postavení v parlamentu nebo jej zlepšují. Údaje $v$ grafu tak naznačují, že se centra politického rozhodování př̀míst'ují z hlavního města do regionů a Praha postupně ztrácí své dominantní postavení, ačkoli jako jediná zvětšuje počet obyvatel i zvyšuje svůj podíl na celkové populaci.

\section{Graf 3: Podíl obyvatel 12 největších měst na celkovém počtu obyvatel mezi lety 1920-2011}

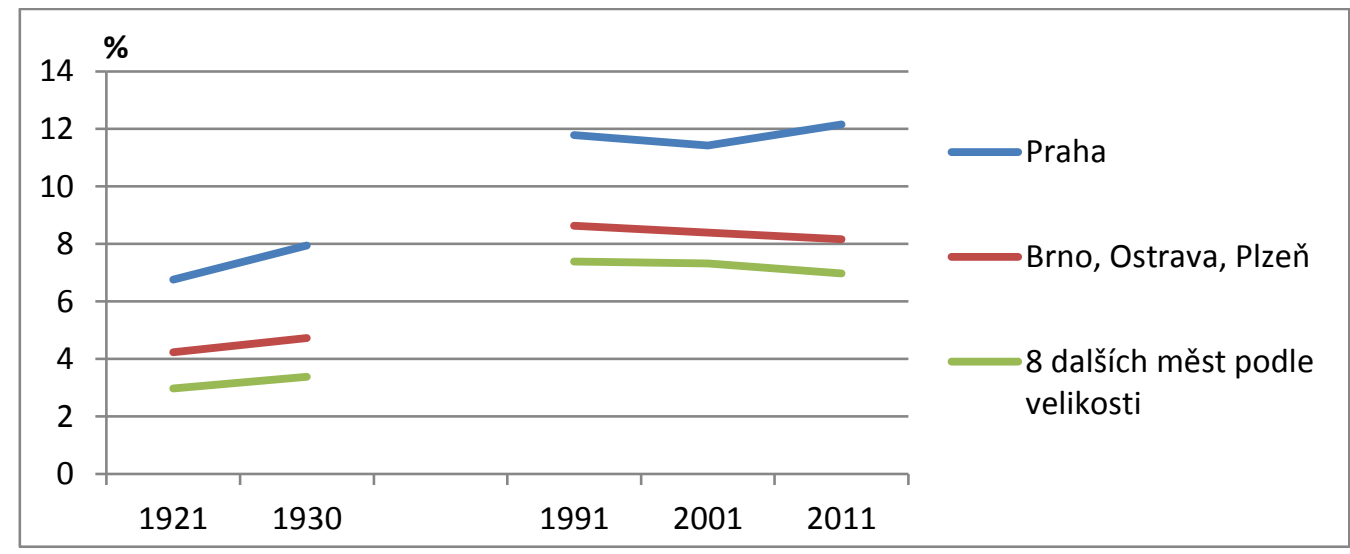

Zdroj: Vlastní výpočty na základě dat ČSÚ

18 Pro rozdělení měst do tří skupin: 1. Praha, 2. Brno, Ostrava, Plzeň, 3. osm dalších největších měst podle počtu obyvatel jsme využili tzv. Zipfův zákon (někdy nazývaný „rank size rule“), který určuje vztah mezi velikostí města a jeho pořadím v rámci sídelního systému (Gregory et al. 2009: 620). Podle empiricky odpozorovaného Zipfova zákona se počet obyvatel nějakého města ve státě přibližně rovná počtu obyvatel nejlidnatějšího města státu děleného číslem značícím pořadí města podle velikosti. Druhé největší město mívá zhruba polovinu počtu obyvatel největšího města, třetí největši město zhruba třetinu počtu obyvatel největšího města. $Z$ toho se dá vyvodit, že počet obyvatel největšího města je zhruba stejně velký, jako počet obyvatel tří dalších největších měst, stejně jako počet obyvatel žijících v dalších 8 městech (tedy městech na 5 . až 12 . místě v pořadí podle velikosti). 
Graf 4: Podíl poslanců z 12 největších měst na celkovém počtu poslanců v letech 1920-2013

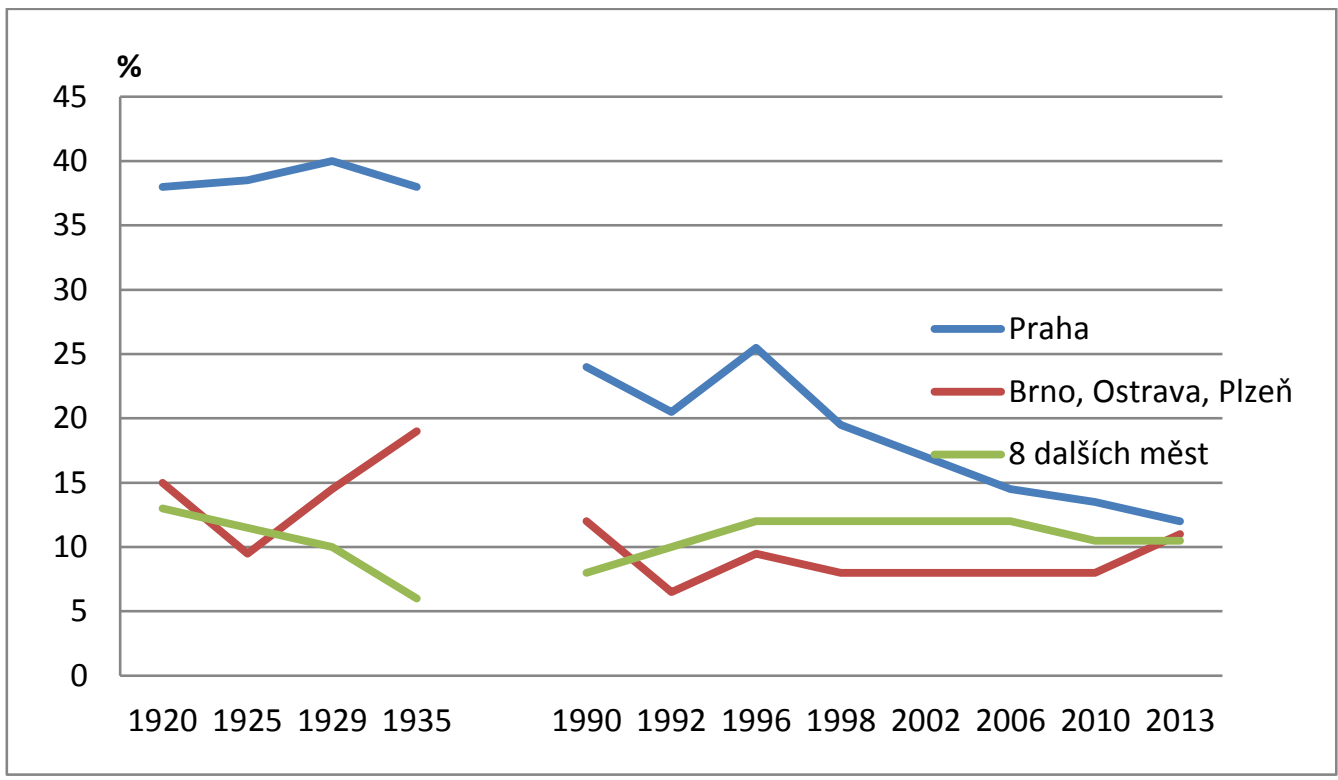

Zdroj: Vlastní výpočty na základě dat ČSÚ

\section{Diskuse}

Všechny provedené analýzy vývoje geografické reprezentativity poslanců ukazují na to, že se vobou obdobích, ve kterých se v Česku konaly svobodné, demokratické a kompetitivní volby, zvyšovala míra geografické reprezentativity poslanců Poslanecké sněmovny parlamentu. Je to dáno především postupnou ztrátou dominance Prahy, a naopak posilováním zastoupení poslanců z regionů a regionálních center $\mathrm{v}$ parlamentu. Zjištěný trend je naprosto zřetelný, co není jasné, jsou prríčiny tohoto vývoje. Pro pozorovaný vývoj existuje několik možných typů vysvětlení. První z nich představuje vysvětlení, které vidí př́činy „na straně nabídky“, tedy v samotných politických stranách. Jde o decentralizaci moci v politických stranách (Linek a Lyons 2008). V dlouhodobém pohledu prrispělo $\mathrm{k}$ decentralizaci moci ve stranách především zavedení principu, že mandát „patř̌i“ zvolenému poslanci a nikoliv straně, ke kterému došlo po roce 1989, a kterým se situace $\mathrm{v}$ postkomunistickém období výrazně odlišila od situace za první republiky. Další decentralizace ve stranách v postkomunistickém období souvisí především s decentralizací významných funkcí státu po roce 2000 a se vznikem samosprávných krajů, které vedly $\mathrm{k}$ vytvoření regionálních politických struktur konkurujících stranickému vedení (Ondráčka 2006). To platí zejména u politických stran úspěšných v krajských volbách. Podle Kylouška (2009) existuje vztah mezi charakterem kandidátní listiny a územní organizací politické strany. 
Vnitrostranická demokratičnost a význam jednotlivých stranických buněk se projevují zejména při výběru kandidátů do voleb. Pravidla výběru kandidátů jsou zpravidla součástí stanov politické strany. Rozhodující tak je, jak významně vedení strany zasahuje do složení kandidátek vzniklých ze stranických primárek (zda vybírá lídra krajské kandidátky nebo zda určuje podíl žen, mladých apod.). Vysoký stupeň decentralizace při výběru kandidátů může zvýšit pravděpodobnost, že se zvolený poslanec nebude ochoten podřizovat autoritě stranického vedení $\mathrm{v}$ důležitém hlasování, zvlášt' pokud stranická centrála má malý vliv na jeho př́padnou další kandidaturu. Naopak vysoká centralizace výběru kandidátů může vést $\mathrm{k}$ nespokojenosti $\mathrm{v}$ regionech a $\mathrm{k}$ vnitrostranickým sporům. ${ }^{19}$

Podle Spáče (2014), který analyzoval kandidátní listiny ve volbách do Poslanecké sněmovny v roce 2013, existuje v tomto ohledu dělící linie mezi zakotvenými a novějšími politickými subjekty, přičemž politické strany a hnutí s delší tradicí ve svých nominacích mnohem více prrihlížejí k proporcionálnímu zastoupení kandidátů z jednotlivých okresů na svých kandidátkách. Novější politické subjekty mají často i menší členskou základnu, ze které by mohly kandidáty do voleb vybírat. Postupný vývoj k decentralizaci politické moci souvisí i s vývojem politických stran v obou sledovaných obdobích. Centra moci byla v počátcích spojena s největšími městy, ve kterých žila a působila politická a ekonomická elita a kde se i formovaly hlavní sociální sítě a kontakty jejich příslušníků. Právě kontakty a pozice potenciálních kandidátů ve straně jsou i klíčové pro získání volitelného místa na kandidátce strany. Jak ukázali Outlý a Prouza (2013), pro získání místa na kandidátce byly v pěti nejvýznamnějších politických stranách v ČR (ODS, ČSSD, KSČM, KDU-ČSL a SZ) do roku 2006 podstatné právě délka členství ve straně a zastávání stranických funkcí odrážejících mocenské postavení ve straně. S prodlužujícími se obdobími fungování „normální demokratické politiky“, nepřrerušované revolucemi, válkami nebo radikálními změnami politického režimu, jak jsme je mohli pozorovat za první republiky a znovu po roce 1989, se zvětšuje „vrstva“ straníků, „čekatelů na funkce“, která je z logiky věci decentralizovaná a která je schopná si vybojovat podstatný podíl na vnitrostranické moci.

Je ovšem možné, že vysvětlení je třeba hledat $\mathrm{v}$ chování voličů, tedy „na straně poptávky“. Pořadí na kandidátní listině významně ovlivňuje to, komu se podaří ve volbách uspět. Až do voleb v roce 2010 platilo, že preferenční hlasy ${ }^{20}$ získávali zejména lidé $\mathrm{v}$ čele kandidátky. Počet preferenčních hlasů udělených kandidátům na nižších místech na kandidátce prudce klesal (Morkes 2008; Voda 2009). Ve volbách v letech 2010 a 2013 se právě díky preferenčním hlasům dostali do sněmovny kandidáti z rưzných pozic na kandidátní listině (dokonce

\footnotetext{
${ }^{19}$ Více o výběru kandidátů v politických stranách viz Outlý, Prouza a kol. (2013).

${ }^{20}$ Pravidla na základě, kterých mohli voliči využívat preferenční hlasy, se v průběhu voleb mezi lety 1990-2013 lišila.
} 
i z posledního místa) a předběhli tak mnohé kandidáty navržené stranou za lídry ve volebním obvodě.

Jak ukázaly analýzy výsledků voleb, až do roku 2006 nebylo pro počet získaných preferenčních hlasů príliš podstatné místo deklarovaného bydliště kandidátů. V následujících dvou volbách, v roce 2010 a 2013, sice preferenční hlasy významně zasáhly do složení sněmovny, avšak důvodem pro využívání preferenčních hlasů byla spíše snaha voličů „potrestat" některé vedoucí představitele politických stran než snaha voličů v některých lokalitách preferovat „místní" kandidáty. $\mathrm{Na}$ druhou stranu si politické strany prú sestavování kandidátek uvědomují, že voliči při svém rozhodování, upřednostňují kromě mediálně známých osobností, především kandidáty, které znají osobně, nebo kandidáty pocházející ze stejného města či oblasti jako voliči, takže se snaží svoji politickou nabídku této poptávce přizpůsobit. Je možné, že strany jednoduše reagují na rostoucí poptávku voličů po lokálních a regionálních kandidátech.

\section{Závěr}

At' je platné kterékoliv z nabízených vysvětlení, která se samozřejmě vzájemně nevylučují, je zřejmé, že prostorové rozmístění místa bydliště navržených kandidátů i zvolených poslanců a jejich změny v čase vypovídají nejen o územní proporcionalitě a geografické reprezentativitě, ale $\mathrm{i}$ o měnících se centrech politické moci. Za první republiky i těsně po roce 1989 měla nejvíce zástupců v parlamentu Praha, v menší míře potom okresy s největšími městy. Postupně se tento vzorec geografické reprezentativity mění ve prospěch jiných území. Praha po celou dobu kontinuálně ztrácí své původně dominantní postavení, a naopak svou pozici posilují další největší města $\mathrm{v}$ pořadí. V posledních volbách $\mathrm{v}$ roce 2013 hodnota míry proporcionality pro Prahu dosáhla hodnoty 1, tedy ideální proporcionality počtu poslanců vzhledem k počtu obyvatel. Pokud srovnáme období první republiky a období po roce 1989 jako dva odlišné časové úseky, zaznamenáme $\mathrm{v}$ nich $\mathrm{v}$ jistém smyslu podobný vývoj charakterizovaný právě počáteční dominancí Prahy, která $\mathrm{v}$ př́padě první republiky zpočátku ještě narůstala a pak začala strmě klesat. Porovnávaná období se ovšem i významně liší navzájem. Zatímco za první republiky existoval mnohem větší počet okresů s žádným či velmi malým počtem zástupců v parlamentu, v období po roce 1990 jsou rozdíly v proporcionalitě jednotlivých okresů obecně mnohem nižší. Analýza jasně potvrdila postupnou decentralizaci a regionalizaci politické moci v Česku, která stojí v protikladu s pozorovaným trendem centralizace moci v ekonomice založené na koncentraci řídících a rozhodovacích ekonomických subjektů do největších měst, zvláště pak do Prahy (Hampl 2007; Blažek a Netrdová 2012).

Ztráta dominantního postavení Prahy a dalších větších měst též souvisí s vývojem politiky jako takové a zejména s klesající důvěrou občanů k politikům i politickým institucím působícím na celostátní úrovni, v kombinaci s přetrvávající 
poměrně vysokou důvěrou v komunální politiky (Čermák a Stachová 2010). Velký pokles důvěry v celostátní politiku byl pozorován zejména po uzavření tzv. opoziční smlouvy, kdy významně poklesla jak volební účast, tak důvěra v celostátní politické instituce (Linek 2013; Čermák a Stachová 2010). Tyto instituce, zejména potom parlament, si mnozí lidé spojují právě s Prahou jako centrem moci. Upřednostňování lokálních kandidátů může být vyjádřením měnících vzorců politické důvěry.

Příští volby a nové personální obsazení Poslanecké sněmovny napoví, jak se bude reprezentativita dále vyvíjet a zda se potvrdí trend prostorové decentralizace bydliště poslanců jako držitelů politické moci. Další výzkum by se měl zaměřit na sledování, zda se větší proporcionalita $\mathrm{v}$ zastoupení poslanců z různých regionů projevuje i v nastavení politik, které mají specifické regionální dopady. Druhým relevantním tématem spojeným s otázkou prostorové reprezentativity poslanců je otázka, zda v Poslanecké sněmovně nadreprezentované regiony nějakým způsobem profitují ze svého postavení např. v již zmiňovaném rozdělování prostředků ze státního rozpočtu. Konečně je relevantní se zabývat otázkou, zda se decentralizace moci na úrovni poslanců projevuje i v personálním složení členů nejužšího vedení jednotlivých politických stran.

\section{Literatura a prameny}

Agnew, John A. (1987): Place and politics: The geographical mediation of state and society. Boston: Allen and Unwin.

Bernard, Josef a Tomáš Kostelecký (2014): „Prostorový kontext volebního chování - jak působí lokální a regionální prostředí na rozhodování voličǔ. “ Sociologický casopis/Cžech Sociological Review 50(1): 3-28. DOI: 10.13060/00380288.2014.50.1.30

Blažek, Jiří a Pavlína Netrdová (2012): „Aktuální tendence lokální diferenciace socioekonomických jevů v Česku: směřuje vývoj $\mathrm{k}$ větší mozaikovitosti prostorového uspořádání?" Geografie 117: 266-288.

Brim, Luboš a Pavel Dufek (2012): „Politická reprezentace individuální a kolektivní: K otázce teoretických základů demokracie na transnacionální úrovni.“ Politologický časopis 19(2): 128-154.

Brokl, Lubomír, Zdenka Mansfeldová a Aleš Kroupa (1998): Poslanci pruního českého parlamentu (1992-96). Working Papers 98:5. Praha: Sociologický ústav AV ČR.

Brokl, Lubomír, Zdenka Mansfeldová a Adéla Seidlová (2001): „Vztah poslanců českého parlamentu k voličům jako problém vertikální odpovědnosti.“ Sociologický časopis/ Cžech Sociological Review 37(3): 297-311.

Broklová, Eva (1992): Ceskoslovenská demokracie: politický systém ĆSR 1918-1938 (Vol. 2). Praha: Sociologické nakladatelství.

Čermák, Daniel a Jana Stachová (2010): „Zdroje institucionální důvěry v České republice." Sociologické ćasopis/ Cžech Sociological Review 46(5): 683-717.

Dahl, Robert A. (1989): Democracy and Its Critics. New Haven: Yale University.

Downs, Anthony (1957): „An Economic Theory of Political Action in a Democracy." The Journal of Political Economy 65(2): 135-150. DOI: 10.1086/257897 
Eulau, Heinz, John Wahlke, Wiliam Buchanan a Leroy Ferguson (1959): „The Role of Representative: Some Empirical Observation on the Theory of Edmund Burke." Americal Political Science Review 53(3): 742-756. DOI: 10.2307/1951941

Eulau, Heinz a Paul D. Karps (1977): „The Puzzle of representation: Specifying Components of responsiveness." Legislative Studies Quaterly 2(3): 233-254.

Gimpel, James G (2008): „Distance-decay in the political geography of friends-andneighbors voting." Political Geography 27: 231-252. DOI: 10.1016/j.polgeo.2007.10.005

Gimpel, James G., Frances E. Lee a Rebecca U. Thorpe (2011): „The wellsprings of candidate emergence: Geographic origns of statewide candidacies in the United States." Political Geography 30: 25-37. DOI: 10.1016/j.polgeo.2010.12.005

Gregory, Derek, Ron Johnston, Geraldine Pratt, Michael Watts a Sarah Whatmore, S. (eds.). (2011): The Dictionary of Human Geography. 5th Edition. Malden, Oxford, Chichester: Wiley-Blackwell.

Hampl, Martin (2007): „Regionální diferenciace současného socioekonomického vývoje v České republice." Sociologický časopis 43(5): 889-910.

Hána, David (2013): „Porcování ministerského medvěda: Souvislost mezi poslaneckými a ministerskými dotacemi v Česku v období 2004-2012.“ Politologická revue 19(2): 76-92.

Hána, David (2014): „Local development implications of pork-barrel: a case study of a Czech district." AUC Geographica 49(2): 73-86. DOI: 10.14712/23361980.2014.17

Chytilek, Roman, Jakub Šedo, Tomáš Lebeda a Dalibor Čaloud (2009): Volebni systémy. Praha: Portál.

Johnston, Ron (1991): A question of place: Exploring the practice of human geography. Oxford: Blackwel

Johnston, Ron, Carol Propper, Rebecca Sarker, Kelvyn Jones, Anne Bolster a Simon Burgess (2005): „Neighbourhood social capital and neighbourhood effects.“ Environment and Planning 37(8): 1443-1459. DOI: 10.1068/a37222

Johnston, Ron, Kelvyn Jones, Carol Propper and Simon Burgess (2007): „Region, Local Context, and Voting at the 1997 General Election in England." American Journal of Political Science 51(3): 640-654. DOI: 10.1111/j.1540-5907.2007.00272.x

Kárník, Zdeněk (2000): Ceské země v ére proní republiky (1918-1938). Díl proní. Vznik, budováni a zlatá léta republiky (1918-1929). Praha: Nakladatelství Libri.

Key, Valdimer O. (1949): Southern politics in state and nation. Knoxville: Alfred A. Knopf.

Kostelecký, Tomáš (1993): „Volby očima geografa.“ in Sýkora, Luděk (ed.). Teoretické prǐstupy a vybrané problémy v současné geografii. Praha: Přírodovědecká fakulta UK.

Kostelecký, Tomáš a Dan Čermák (2004): „Vliv teritoriálně specifických faktorů na formování politických orientací voličů. “ Sociologický časopis/Czech Sociological Review 40(4): 469-488

Kostelecký, Tomáš, Renáta Mikešová, Markéta Poláková, Daniel Čermák, Josef Bernard a Martin Šimon (2014): Koho voli V aši sousedé? Prostorové vzorce volebního chováni na územi Česka od roku 1920 do roku 2006, jejich żmèny a možné príćiny. Praha: Sociologické nakladatelství SLON.

Kyloušek, Jakub (2007): „České parlamentní volby 2006: analýza kandidátních listin.“ Politologický ćasopis 1: 79-92.

Latner, Michael a Anthony McGann (2005): „Geographical representation under proportional representation: The cases of Israel and the Netherlands." Electoral studies 24: 709-734. DOI: 10.1016/j.electstud.2005.02.007 
Lee, Frances E. (2007): „Geographic Representation and the U.S. Congress.“ Maryland Law Review 67(1): 51-61.

Linek, Lukáš a Pat Lyons (2008): „Does Party Organization Still Matter in the Czech Republic? An Examination of the Czech Christian Democratic Party. " Transitions 48(1): 103-131.

Linek, Lukáš (2009): „Socio-demografická struktura poslanců a její vliv na politické postoje." In: Mansfeldová, Zdenka a Lukáš Linek: Ceský parlament v drubé dekádě demokratického vývoje. Praha: Sociologický ústav Akademie věd ČR,v.v.i.

Linek, Lukáš (2013): Kam se ztratili voliči? Vysvètleni volebni účasti v České republice v letech 1990-2010. Brno: CDK.

Machonin, Petr (2011): „Politická elita 1989-2007.“ In: Frič, Pavol, Petr Machonin, M.

Nekola a Milan Tuček: Elity v čské postsocialistické transformaci (1989-2007). Studie Národohospodářského ústavu Josefa Hlávky 8/2011.

Malcová, Karolína (2012): „Lokální aspekt volební podpory kandidátů do Senátu Parlamentu ČR." Sociologický časopis/Czech Sociological Review 48(2): 283-313.

Manin, Bernard (1997): The principles of representative government. Cambridge University Press, online (http://www.fflch.usp.br/dcp/assets/docs/PDF/Manin_Edital.pdf)

Mansbridge, Jane (2003): „Rethinking Representation.“ The American Political Science Review 97(4): 515-528. DOI: 10.1017/S0003055403000856

Mansfeldová, Zdenka (2015): „The Czech parliament on the road to professionalization and stabilization." In: Elena Semenova, Michael Edinger a Heinrich Best (eds) (2015): Parliamentary Elites in Central and Eastern Europe. Recruitment and representation. London and New York: Routledge.

Morkes, Jan (2008): „Analýza preferenčního hlasování ve volbách do PSP ČR.“ European Electoral Studies 3(1): 1-33

Novák, Miroslav (1997): „Is There One Best Model of Democracy? Efficiency and Representativeness: Theoretical Revolution or Democratic Dilemma?." Czech Sociological Review 5(2): 131-157.

Ondráčka, David et al. (2006): Transparentni procesy v politickém roz̧odování. Sborník textio kproblému korupce politických predstaviteli. Transparency International Online (http://www.transparency.cz/transparentni-procesy-politickem-rozhodovani-sborniktextu-k/)

Outlý, Jan a Jan Prouza a kol. (2013): Navrhováni a výbèr kandidátu. Politické strany v ČR a ve strední Evropě. Olomouc: Civipolis.

Pitkin, Hanna Fenichel (1967): The Concept of Representation. Berkeley: University of California Press.

Pollak, Johannes, Jozef Bátora, Monika Mokre, Emanuel Sigalas a Peter Slominski (2009): „On Political Representation: Myths and Challenges." RECON Online Working Paper Series http://www.reconproject.eu/main.php/RECON_wp_0903.pdf? fileitem=505119 67.

Poláková, Markéta a Tomáš Kostelecký (2016): „Povolání zvolených poslanců za první republiky a dnes." Stredoevropské politické studie XVIII(1): 1-30. DOI: 10.5817/CEPSR.2016.1.1

Rakušanová Guasti, Petra (2009a): „Role poslance a její percepce.“ In: Mansfeldová, Zdenka a Lukáš Linek. Ceský parlament v drubé dekádè demokratickébo vývoje. Praha: Sociologický ústav Akademie věd ČR,v.v.i. 
Rakušanová Guasti, Petra (2009b): „Konceptuální zarámování reprezentace.“ Socioweb 2009 Online (http://www.socioweb.cz/index.php?disp=teorie\&shw=414\&lst=107)

Spáč, Peter (2014): „Kandidátní listiny.“ In: Havlík, Vlastimil a kol.: Volby do Poslanecké snémovny 2013. Brno: MUNI Press

Squires, Judith (1999): Gender in political theory. 1st ed. Cambridge: Polity Press.

Stolz, Klaus (2003): „Moving up, moving down: Political careers across territorial levels.“ European Journal of Political Research 42: 223-248. DOI: 10.1111/1475-6765.00081

Tuček, Milan a kol. (2006): Ceské elity po patnácti letech transformace. Praha: Sociologický ústav Akademie věd ČR.

Urbinati, Nadia a Mark E. Warren (2008): „The Concept od Representation in Contemporary Democratic Theory.“ The Annual Review of Political Science 11(1): 387-412. DOI: 10.1146/annurev.polisci.11.053006.190533

Voda, Petr (2009): Efekt kandidáta ve volbách v českém prostredí. Diplomová práce. Masarykova Univerzita Brno. Fakulta sociálních studí́.

Voda, Petr a Michal Pink (2009): „Kandidáti v poslaneckých volbách. Analýza preferenčního hlasování ve volbách do PS PČR v roce 2006.“ Strédoevropské politické studie XI(2-3): 163-180.

Voda. Petr (2010): „Efekt kandidáta.“ In: Balík, Stanislav (ed): Volby do Poslanecké snèmovny v roce 2010. Brno: CDK.

Voda, Petr (2013): „Analýza preferenčního hlasování.“ In: Balík, Stanislav a kol. (ed). Krajské volby 2012. Brno: CDK.

Voda, Petr (2014): „Efekt kandidáta ve volbách do Poslanecké sněmovny v roce 2013.“ In: Havlík, Vlastimil a kol. (eds.). Volby do Poslanecké snèmovny 2013. Brno: Mezinárodní politologický ústav FSS MU.

Weissberg, Robert (1978): „Collective vs. Dyadic Representation in Congress.“ The American Political Science Review 72(2): 535-547. DOI: 10.2307/1954109

\section{The geographical representativeness of deputies elected to the Chamber of Deputies of the Czech Parliament during the First Republic (1918-1938) and after 1989}

\section{SUMMARY}

The article focuses on an analysis of the geographical representation of deputies elected to the Lower Chamber of parliament on the territory of Czechia in two historical periods - the interwar period (1918 -1938) and the period after 1989. According to Pitkin's theoretical framework of various types of representation, geographical representation was considered as a part of descriptive representation. In accordance with electoral law, each electoral district has its own representative or representatives in a representative body; thus, geographical representation is preferred over other forms of descriptive representation and, therefore, a certain degree of geographic representation is automatically guaranteed. Elected deputies could be regarded as political representatives 
of citizens living in electoral districts. However, current deputies, especially in countries using electoral systems of proportional representation, represent the ideology of the party to which they belong rather than the region. Many scholars argue that, nowadays, elections are not about electing people who voters are familiar with, but about political ideologies and programs; that is, voters now choose a political party or program that best reflects their views. However, voters also take into account whether candidates are similar to them in terms of class or gender or whether they are from the same region. Empirical studies show that the place of residence of candidates affects their popularity among voters. The existence of the "friends-and-neighbors effect" shows that at least some voters favor a local candidate, even though it may mean changing their traditional party preferences, because they either know the candidate personally or believe that he or she will represent and promote local interests. For this reason, it is useful for political parties to have candidates from different regions on the electoral list in order to enable voters to identify with local candidates. Thus, even in cases where no legal requirements exist for candidates to live in the region or city where they run for office, electoral competition encourages the creation of regionally balanced electoral lists.

We analyzed data on the place of residence of all deputies of the Lower Chamber of the Czech parliament in both of the historical periods in question. For the analysis of the geographical representation of Czech deputies we used the method developed by Latner and McGann (2005), which employs a proportionality ratio calculated by dividing the percentage of members of parliament residing in the district by the percentage of the population living in the district. All analyses indicate an increasing level of geographic representation on the part of deputies in the Czech Parliament in both historical periods. This is/was primarily due to Prague's gradual loss of dominance and the strengthening of the representation of deputies from the other regions and smaller regional centers. We also compared data on both population and political representation in parliament from the twelve most populated cities in the Czech Republic based on the rank-size rule principle, which assumes that the population of the largest city is roughly equal to the populations of the other three largest cities combined, as well as the populations of the cities ranked from 5th to 12th place combined. The proportion of Prague's population relative to the Czech population in total was larger than the combined proportions of the populations of the other two groups of large Czech cities and, moreover, gradually increased over time. The proportion of deputies with a residence in Prague generally decreased. In contrast, the other two groups of cities increased both their share of the total Czech population and their share of Czech members of parliament. In short: the relative weight of Prague residents among Czech national political elite has been diminishing constantly over the observed period. In 2013, the city of Prague provided no more deputies than was proportional to the population of the city.

There are several possible explanations for this trend. The first explanation sees possible causes on the "supply side" of the electoral process - within political parties themselves. It was observed that over the course of the studied periods, power in political parties was heavily decentralized. Consequently, the decentralization of power within parties led to the creation of more geographically proportional electoral lists. The decentralization of power within political parties is linked to the changing character of the mandate between the interwar period, when the parliamentary seat was de facto legally owned by political parties, and the period after 1989, when the Constitution explicitly 
claimed that the mandate "belongs" to the elected deputy. The other factor contributing to the decentralization of power within established political parties was the gradual decentralization of power within the state, especially after the new tier of self-government - the regions - was established in 2000. It is also possible to find the explanation in the "demand side" of the electoral process - within voters. It was observed that over the course of time, voters learned how to use their powers and how to exercise them through, for example, preferential votes. The number of preferential votes increased, first as a tool to "punish" unpopular politicians, later as a tool to prefer local candidates. Consequently, political parties were pushed to react to voter demand and became more careful about the geographical representativeness of their candidates.

The analysis clearly confirms the gradual decentralization and regionalization of political power in the country, which stands in contrast to the centralization of power in the economy, this latter trend apparent from the concentration of economic management and decision-making in the largest cities, especially in Prague. The loss of the dominant position of deputies from Prague and the other biggest cities is also related to a decline in trust in national political institutions such as parliament as well as to a general decrease in electoral turnout. 